\title{
PENGARUH PENGGUNAAN MEDIA AUDIO VISUAL TERHADAP KETERAMPILAN MENULIS TEKS RESENSI SISWA KELAS XI SMKS ULUMUDDIN LHOKSEUMAWE
}

\author{
oleh \\ Murahmanita, Sayni Nasrah*, \& Trisfayani \\ *Dosen Program Studi Pendidikan Bahasa Indonesia, FT Universitas Malikussaleh \\ Surel: sayni.nasrah@unimal.ac.id
}

\begin{abstract}
ABSTRAK
Penelitian ini berjudul pengaruh penggunaan media audio visual terhadap keterampilan menulis teks resensi siswa kelas XI SMKS Ulumuddin Lhokseumawe. Tujuan penelitian ini untuk mengetahui pengaruh penggunaan media audio visual terhadap keterampilan menulis teks resensi siswa kelas XI SMKS Ulumuddin Lhokseumawe. Pendekatan yang digunakan dalam penelitian ini adalah deskriptif kuantitatif menggunakan model eksperimen dengan rancangan control group pre-test dan post-test design. Sumber data atau objek penelitian dalam penelitian ini adalah seluruh peserta didik kelas XI putri yang terdiri dari 2 kelas dengan jumlah 27 peserta didik dan keseluruhannya dijadikan objek penelitian. Kelas XI MM sebagai kelas kontrol dan kelas XI TGB sebagai kelas eksperimen. Teknik pengumpulan data menggunakan tes awal (pre-test) dan tes akhir (post-test). Hasil penelitian memperlihatkan perbedaan nilai rata-rata pre-test dan post-test kelas eksperimen dan kontrol. Rata-rata nilai pre-test kelas kontrol yaitu, 78,44, sedangkan nilai pada hasil post-test adalah 89,78. Nilai rata-rata (mean) pada hasil pre-test kelas eksperimen adalah 68,22 , sedangkan pada hasil post-test adalah 90,89. Hasil tersebut memperlihatkan terdapat pengaruh yang signifikan dari penggunaan media audio visual terhadap keterampilan menulis teks resensi dengan kata lain $\mathrm{H}_{\mathrm{a}}$ diterima dan $\mathrm{H}_{0}$ ditolak.
\end{abstract}

Kata Kunci: Audio Visual, Menulis, Teks Resensi 


\section{PENDAHULUAN}

Menulis adalah keterampilan produktif dengan menggunakan tulisan. Menulis bukanlah sekedar menyalin katakata dalam kalimat-kalimat, melainkan juga mengembangkan dan menuangkan pikiran-pikiran dalam suatu struktur tulisan yang teratur. Dengan demikian, keterampilan menulis tentunya harus dapat dikuasai dan juga dikembangkan oleh peserta didik (Cahyani dalam Hutabarat, 2017: 14).

Hutabarat (2017:19) juga mengatakan keterampilan menulis merupakan salah satu keterampilan berbahasa yang memiliki peran penting dalam kehidupan manusia. Menulis bukan hanya diartikan sebagai sesuatu yang berhubungan dengan menyalin, mencatat, dan mengerjakan sebagian tugas sekolah, tetapi menulis berkaitan dengan ketepatan penggunaan kata-kata, mempergunakan rangkaian bahasa tulis yang baik dan benar. Tanpa keterampilan menulis, peserta didik akan mengalami kesulitan dalam melaksanakan tugas tersebut.

Sulitnya keterampilan menulis ini dibuktikan oleh Septiaji (2015) yang mengemukakan bahwa salah satu hal yang paling dihindari dalam ruang lingkup keterampilan berbahasa adalah menulis. Tidak hanya Septiaji, Khotimah dan Kartika (2016:492) menyatakan bahwa menulis dapat dikatakan keterampilan berbahasa yang paling rumit di antara jenis-jenis keterampilan berbahasa lainnya. Berdasarkan pendapat tersebut dapat disimpulkan bahwa keterampilan menulis merupakan keterampilan yang paling sulit dibandingkan keterampilan berbahasa lainnya.

Salah satu keterampilan menulis yang dituntut pada kurikulum 2013 tingkat SMK kelas XI semester genap adalah keterampilan menulis teks resensi. Keterampilan menulis teks resensi ini tercantum pada KD 4.14 "Menyusun sebuah resensi dengan memperhatikan hasil perbandingan beberapa teks resensi”.
Pada meteri tersebut peserta didik dapat mengungkapkan ide, pikiran, pengetahuan dengan menggunakan kemampuan keterampilan menulis teks resensi. Ketepatan dalam penggunaan kata-kata, kesesuaian isi tulisan terhadap materi pembelajaran, serta aspek-aspek penting dalam menulis teks resensi menjadi hal yang penting untuk diperhatikan dalam keterampilan menulis, terutama terhadap kemampuan keterampilan menulis suatu teks resensi pada pembelajaran.

Menulis teks resensi adalah menyampaikan suatu informasi kepada pembaca apakah hasil karya sastra tersebut patut mendapat sambutan dari masyarakat atau tidak (Dalman, 2014:231). Dengan salah satu materi pembelajaran resensi, peserta didik dapat melatih keberanian dalam menulis untuk menyampaikan informasi kepada pembaca, untuk itu diperlukan adanya keterampilan yang baik untuk menulis, sehingga apa yang ingin disampaikan sesuai dengan apa yang diharapkan.

Menulis teks resensi menuntut peserta didik untuk dapat terampil dalam menulis. Adapun keterampilanketerampilan dasar yang harus diketahui oleh peserta didik yaitu ketepatan dalam penggunaan kata-kata, ketepatan dalam penggunaan kata-kata berkaitan dengan ketepatan penggunaan pilihan kata atau diksi dalam menulis. Kemudian keterampilan menuangkan gagasan pemikiran dalam menulis, gagasan pemikiran tersebut berupa keterampilan peserta didik terhadap hasil pemikiran yang akan dituliskan peserta didik. Selanjutnya, penggunaan rangkaian bahasa tulis yang baik dan benar. Rangkaian bahasa tulis yang baik dan benar dalam menulis tidak terlepas dari pedoman umum ejaan bahasa Indonesia yang telah ditentukan. Pembelajaran teks resensi berkaitan dengan tulisan ilmiah yang membahas isi dari karya sastra tersebut, termasuk kelemahan dan keunggulannya untuk diberitahukan 
kepada pembaca. Dengan demikian, dapat melatih peserta didik dalam keterampilan menulisnya.

Rendahnya keterampilan menulis teks resensi ini dibuktikan oleh beberapa penelitian. Pertama penelitian yang dilakukan oleh Mayaningrum (2010), dengan judul "Peningkatan Kemampuan Menulis Resensi Siswa Kelas XII IPA 1 SMA Negeri 3 Jombang dengan Menggunakan Metode CIRC". Rendahnya keterampilan menulis teks resensi pada kelas XII IPA 1 SMA Negeri 3 Jombang terjadi karena peserta didik mengalami kesulitan dalam menulis teks resensi, ketidaktahuan peserta didik tentang apa yang harus ditulis dalam teks resensi dan ketidaktahuan peserta didik mengenai format penulisan teks resensi yang baik.

Kedua, penelitian yang dilakukan oleh Pohan (2014), dengan judul "Pengaruh Model Pembelajaran Collaborative Learning Terhadap Kemampuan Menulis Resensi Cerpen oleh Siswa Kelas XI SMA Persiapan Stabat Tahun Pelajaran 2013/2014". Rendahnya keterampilan menulis cerpen pada kelas XI SMA Persiapan Stabat dipengaruhi oleh kurangnya minat peserta didik dalam membaca cerpen, belum sepenuhnya memahami unsur intrinsik dan ekstrinsik cerpen, dan kurangnya berlatih dalam meresensi cerpen.

Ketiga, penelitian yang dilakukan oleh Agustin (2017), dengan judul "Peningkatan Kemampuan Menulis Resensi Novel Menggunakan Strategi Pemodelan". Rendahnya keterampilan menulis teks resensi pada novel tersebut terjadi akibat kurangnya antusias peserta didik dalam membaca dan strategi pembelajaran yang digunakan kurang efektif.

Berdasarkan observasi awal selama PPL dari bulan Agustus sampai bulan Oktober yang peneliti lakukan di SMK Swasta Ulumuddin Lhokseumawe penulis mendapati beberapa permasalahan dalam menulis resensi. Pertama, kurangnya antusias dalam membaca. Kurangnya kesadaran yang dilakukan oleh peserta didik untuk lebih banyak membaca menjadi salah satu penyebab kurangnya pemahaman peserta didik dalam menulis teks resensi. Antusias peserta didik dalam menulis teks resensi menjadi penghambat proses pembelajaran untuk memperoleh pengetahuan lebih luas terhadap materi teks resensi.

Kedua, strategi pembelajaran yang digunakan kurang efektif dan monoton. Proses pembelajaran dengan menggunakan strategi kurang tepat akan menjadi salah satu pemicu kesuksesan pembelajaran. Dengan demikian, ketepatan pemilihan strategi pembelajaran perlu untuk diperhatikan agar tidak monoton. Kegiatan pembelajaran yang tidak kreatif menjadikan proses pembelajaran menjadi kurang efektif, hal ini disebabkan karena kegiatan pembelajaran tidak berkembang dan hanya terpacu pada kegiatan yang sama.

Ketiga, kurangnya pemahaman peserta didik dalam menulis teks resensi. Ketidakpahaman peserta didik terhadap materi pembelajaran menjadi penyebab rendahnya keterampilan menulis resensi pada peserta didik, kurangnya pemahaman materi pembelajaran menjadi pusat perhatian pendidik untuk memberikan penjelasan secara terperinci pada kegiatan belajar mengajar.

Keempat, kurangnya pemanfaatan media berbasis ilmu pengetahuan dan teknologi. Proses pembelajaran tidak hanya bersumberkan dari buku saja, pendidik dapat memanfaatkan kecanggihan teknologi berupa pemanfaatan audio visual dalam kegiatan belajar mengajar. Dengan demikian, akan membantu pendidik untuk memberikan pemahaman terhadap materi pembelajaran resensi yang akan dipelajari.

Salah satu cara yang dapat dilakukan untuk mengatasi rendahnya keterampilan menulis teks resensi peserta 
didik yaitu dengan penggunaan media audio visual. Rahmawati (2011:3) mengemukakan bahwa kegiatan pembelajaran dengan menggunakan media audio visual secara tidak langsung memberikan dampak yang baik bagi kemajuan dalam hal penyampaian materi. Selain itu, pemanfaatan penggunaan media audio visual dalam pembelajaran mampu memberikan respons positif dan mampu meningkatkan pemahaman peserta didik terhadap materi pembelajaran yang disampaikan (Dadang, dkk. dalam Rakhman, dkk., 2014:10). Pendapat lain dari Rusman (dalam Kharisma, 2018:9) mengemukakan bahwa penggunaan media audio visual sebagai alat bantu untuk pembelajaran yang lebih jelas.

Penelitian yang akan peneliti lakukan relevan dengan beberapa penelitian sebelumnya. Pertama, Yuliapitri (2016) dengan penelitiannya yang berjudul "Hubungan Kemampuan Memahami Resensi dengan Kemampuan Menulis Resensi Siswa Kelas XI IPA SMA Negeri 2 Tilatang Kamang Kabupaten Agam". Relevansi pada penelitian tersebut berkaitan dengan persamaan dan perbedaan. Persamaan antara peneliti sebelumnya dengan peneliti yaitu sama-sama meneliti tentang keterampilan menulis teks resensi peserta didik pada mata pelajaran bahasa Indonesia, sedangkan perbedaannya terletak pada lokasi penelitian yang akan dilakukan, perbedaan lainnya juga dapat dilihat pada penelitian sebelumnya mengkaji hubungan kemampuan memahami teks resensi dengan kemampuan menulis teks resensi, sedangkan penelitian yang akan peneliti lakukan yaitu ingin mengetahui pengaruh penggunaan media audio visual terhadap keterampilan menulis teks resensi.

Kedua, Windari (2016) dengan penelitiannya yang berjudul "Pengaruh Penggunaan Media Film Terhadap Keterampilan Menulis Cerpen Siswa
Kelas XII SMA Negeri 1 Lengayang Kabupaten Pesisir Selatan". Relevansi pada penelitian tersebut yaitu, persamaan antara penelitian yang dilakukan oleh Windari dengan peneliti yaitu terdapat pada kemampuan menulis peserta didik, sedangkan perbedaanya terdapat pada materi pembelajarannya, kelas, serta lokasi penelitian. Materi pembelajaran yang peneliti sebelumnya lakukan yaitu pada materi cerpen, berbeda halnya dengan peneliti pada materi teks resensi. Perbedaan lainnya pada objek penelitian yang dilakukan oleh Windari pada siswa kelas XII di SMA Negeri 1 Lengayang Kabupaten Pesisir Selatan, sedangkan peneliti pada kelas XI di SMKS Ulumuddin Lhokseumawe.

Ketiga, Afianti (2014) dalam penelitiannya yang berjudul "Pengaruh Penggunaan Media Audio Visual Terhadap Peningkatan Keterampilan Menulis Puisi Siswa Kelas IX MTS Jabal Nur Cipondoh Tangerang Tahun Pelajaran 2014/2015". Relevansi penelitian terdahulu dan penelitian peneliti memiliki kesamaan yaitu pada pengaruh media audio visual terhadap keterampilan menulis peserta didik. Perbedaannya penelitian yang dilakukan oleh Afianti pada keterampilan menulis puisi, sedangkan peneliti terhadap kemampuan menulis teks resensi. Perbedaan lainnya pada kelas, dan lokasi yang tentunya juga berbeda dengan yang peneliti lakukan.

Penggunaan media audio visual dugaan penulis menjadi salah satu cara yang sangat efektif diterapkan dalam materi teks resensi khususnya terhadap keterampilan menulis peserta didik. Melalui media audio visual tersebut, diharapkan dapat menjadi salah satu alternatif untuk tercapainya hasil pembelajaran secara optimal. Dengan demikian, keberhasilan dalam proses belajar dan mengajar akan tercapai.

Berdasarkan penjelasan tersebut, peneliti beranggapan bahwa penggunaan media audio visual dapat digunakan untuk 
membantu peserta didik dalam kemampuan menulis teks resensi. Penggunaan media yang tidak membosankan dapat mengembangkan kemampuan menulis peserta didik. Oleh sebab itu, peneliti bermaksud melakukan penelitian ini dengan tujuan untuk mengetahui pengaruh penggunaan media audio visual terhadap keterampilan menulis teks resensi siswa kelas XI SMKS Ulumuddin Lhokseumawe. Alasan memilih sekolah SMKS Ulumuddin karena kurangnya pemanfaatan penggunaan media audio visual dan penelitian ini belum pernah dilakukan sebelumnya di sekolah tersebut.

\section{TINJAUAN TEORITIS}

Media berasal dari bahasa latin dan merupakan bentuk jamak dari kata medium. Secara harfiah, media berarti perantara atau pengantar. Media dalam bahasa Arab " artinya perantara atau pengantar pesan dari pengirim kepada penerima pesan, sedangkan dalam dunia pendidikan media dapat diartikan sebagai alat bantu yang dapat dijadikan penyalur pelajaran pendidik (Muslich dalam Halifah, 2015:12). Media merupakan segala sesuatu yang berhubungan dengan penyampaian informasi yang dapat menyalurkan suatu informasi dari orang yang memberi informasi kepada orang yang akan diberikan informasi baik berupa perangkat keras atau perangkat lunak (Kurnia, dkk., 2016:842).

Susanti dan Affrida (2018:4) media terbagi menjadi 3 yaitu: (1) media visual, (2) media audio, dan (3) media audio visual.

\section{(1) media visual}

Media visual adalah suatu alat atau sumber belajar yang didalamnya berisikan pesan, informasi khususnya materi pelajaran yang disajikan secara menarik dan kreatif dan diterapkan dengan menggunakan indera pengelihatan. Jadi media visual ini dapat dipergunakan oleh orang-orang tunanetra karena media visual dapat digunakan dengan indera pengelihatan.

(2) media audio

Media audio adalah jenis media pembelajaran atau sumber belajar yang berisikan pesan atau materi pelajaran yang disajikan secara menarik dan kreatif dan diterapkan dengan menggunakan indera pendengaran saja, karena media audio hanya berupa suara.

(3) media audio visual

Media audio visual adalah jenis media pembelajaran atau sumber belajar yang berisikan pesan atau materi pelajaran yang dibuat menarik dan kreatif dengan menggunakan indra pendengaran dan penglihatan. Media audio visual ini berupa suara dan gambar.

\section{METODE PENELITIAN}

Penelitian ini dikategorikan jenis penelitian kuantitatif. Metode yang digunakan deskriptif kuantitatif. Jenis penelitian ini mengacu pada tujuan penelitian, yaitu mendeskripsikan pengaruh penggunaan media audio visual terhadap keterampilan menulis teks resensi siswa kelas XI SMK Swasta Ulumuddin Lhokseumawe. Sumber atau objek penelitian ini terdiri dua kelas sebanyak 27 peserta didik. Satu kelas sebagai kelas kontrol dan satu kelas sebagai kelas eksperimen. Berdasarkan hasil tes pengamatan sebelumnya dan wawancara dengan pendidik mata pelajaran Bahasa Indonesia kelas XI SMK bahwa kelas XI MM memiliki nilai keterampilan menulis yang lebih baik dari pada kelas XI TGB, sehingga pada penelitian ini kelas XI TGB mendapatkan perlakuan berupa penggunaan media audio visual terhadap keterampilan menulis teks resensi. Hal ini menunjukkan bahwa kelas XI MM sebagai kelas kontrol dan XI TGB sebagai kelas eksperimen yang mendapatkan perlakukan dalam penelitian ini. Teknik pengumpulan data yang digunakan dalam penelitian ini 
adalah teknik tes. Tes yang diberikan berupa tes awal (pre-test) dan tes akhir (post-test) berupa penelitian keterampilan menulis teks resensi. Data penelitian ini diolah dengan menggunakan aplikasi SPSS versi 20 for windows. Pengolahan data dilakukan untuk menjawab masalah dalam penelitian. Pengolahan data tersebut dilakukan melalui beberapa tahapan, yaitu:

1) memeriksa hasil kerja siswa dalam menulis teks resensi berupa aspek kreativitas tulisan, kelengkapan informasi, struktur teks ulasan, pemilihan kata, penulisan kalimat, dan penulisan ejaan.

2) memeriksa hasil kerja siswa dengan memberikan skor sesuai dengan aspek pedoman penilaian yang telah ditentukan.

3) merekap data penelitian pre-test dan post-test kelas eksperimen dan kelas kontrol yang diperoleh siswa dalam tabel.

4) melakukan uji prasyarat normalitas dan homogenitas dari hasil tes yang dilakukan dengan menggunakan aplikasi SPSS versi 20 for windows sebelum melakukan uji hipotesis.

\section{HASIL DAN PEMBAHASAN}

Penelitian ini dilaksanakan pada dua kelas yang berbeda yaitu kelas XI-Multimedia sebanyak 18 siswa sebagai kelas kontrol dan kelas XI-TGB sebanyak 9 siswa sebagai kelas eksperimen. . Data yang dikumpulkan dalam penelitian ini berupa hasil nilai kerja yang dilakukan oleh siswa dalam keterampilan menulis teks resensi film. Tes yang dilakukan berupa tes awal (pre-test) dan tes akhir (post-test). Data pre-test dan post-test diolah berdasarkan pedoman penskoran tes keterampilan menulis teks resensi pada rentang nilai sampai dengan skala 100. Berikut ini data yang telah diperoleh dari tes keterampilan menulis teks resensi siswa.

Tabel Nilai Tes Awal Kelas Eksperimen
Tes awal siswa (pre-test) kelas eksperimen

\begin{tabular}{|c|c|c|}
\hline 45 & 64 & 77 \\
\hline 58 & 71 & 78 \\
\hline 63 & 76 & 82 \\
\hline
\end{tabular}

Tabel Nilai Tes Akhir Kelas Eksperimen

Tes akhir siswa (post-test) kelas eksperimen

\begin{tabular}{|c|c|c|}
\hline 81 & 91 & 95 \\
\hline 82 & 91 & 97 \\
\hline 88 & 93 & 100 \\
\hline
\end{tabular}

Tabel Nilai Tes Awal Kelas Kontrol

Tes awal siswa (pre-test) kelas kontrol

\begin{tabular}{|c|c|c|c|c|c|}
\hline 62 & 70 & 73 & 79 & 83 & 87 \\
\hline 66 & 70 & 78 & 80 & 84 & 94 \\
\hline 67 & 71 & 79 & 82 & 87 & 100 \\
\hline
\end{tabular}

Tabel Nilai Tes Akhir Kelas kontrol

\begin{tabular}{|l|l|l|l|l|l|}
\hline \multicolumn{5}{|c|}{ Tes awal siswa (post-test) kelas kontrol } \\
\hline 74 & 84 & 90 & 92 & 94 & 95 \\
\hline 78 & 86 & 91 & 93 & 95 & 97 \\
\hline 81 & 88 & 91 & 94 & 95 & 98 \\
\hline
\end{tabular}

Hasil penelitian memperlihatkan perbedaan nilai rata-rata pre-test dan posttest kelas eksperimen dan kontrol. Ratarata nilai pre-test kelas kontrol yaitu, 78,44 , sedangkan nilai rata-rata (mean) pada hasil post-test adalah 89,78. Hasil post-test siswa kelas kontrol lebih tinggi dari pada hasil pre-test, hal tersebut karena pada post-test sudah terlebih dahulu diberikan materi.

Nilai rata-rata (mean) pada hasil pre-test kelas eksperimen adalah 68,22, sedangkan nilai rata-rata (mean) pada hasil post-test adalah 90,89. Hasil posttest siswa pada kelas eksperimen lebih tinggi dari pada hasil pre-test hal tersebut karena pada post-test sudah terlebih dahulu diberikan perlakuan penggunaan media audio visual berupa video pembelajaran, tetapi nilai rata-rata kelas kontrol tidak terlalu mengalami kenaikan yang signifikan seperti pada kelas eksperimen. Peningkatan yang terjadi antara nilai pre-test dan post-test pada kelas eksperimen adalah sebesar 22,67, 
sedangkan peningkatan antara nilai pretest dan post-test pada kelas kontrol yaitu 11,34 .

Hasil tersebut memperlihatkan terdapat pengaruh yang signifikan dari penggunaan media audio visual terhadap keterampilan menulis teks resensi siswa kelas XI SMKS Ulumuddin Lhokseumawe. Dengan demikian, membuktikan bahwa pada penelitian ini $\mathrm{H}_{\mathrm{a}}$ diterima dan $\mathrm{H}_{0}$ ditolak.

\section{PEMBAHASAN}

Hasil awal keterampilan menulis teks resensi pada kelas kontrol diketahui berdasarkan pre-test. Pre-test tersebut bertujuan untuk mengetahui keterampilan awal siswa dalam menulis teks resensi, penelitian tersebut dilakukan secara sistem daring (dalam jaringan) dengan aplikasi WhatsApp. Hasil pre-test akan menunjukkan kesulitan-kesulitan siswa dalam menulis teks resensi. Setelah pretest selesai, tahap berikutnya yaitu memberikan materi pembelajaran mengenai teks resensi berupa tulisan dalam bentuk (word) kepada siswa. Setelah mengirimkan materi pembelajaran, lalu memberikan tes akhir kemudian siswa mengirimkan hasil menulis melalui via WhatsApp. Hasil pretest dan post-test kelas kontrol akan dibandingkan berdasarkan nilai tes keterampilan menulis siswa.

Berdasarkan hasil pre-test pada kelas kontrol yang diperoleh terlihat beberapa kesulitan siswa dalam menulis teks resensi. Kesulitan tersebut berupa kurangnya kreativitas dalam menulis teks resensi, kelengkapan menuliskan informasi dalam teks resensi masih kurang, struktur teks ulasan yang tidak runtut, dan kurang tepat dalam menuliskan ejaan. Hasil tes awal yang diberikan menunjukkan pemahaman siswa tentang keterampilan menulis teks resensi masih terbatas.

Hasil post-test pada kelas kontrol terlihat sedikit lebih meningkat dari sebelumnya setelah diberikan materi pembelajaran mengenai teks resensi. Penulisan teks resensi siswa pada tes akhir sudah memperlihatkan hasil yang sedikit lebih baik. Meskipun jika dilihat dari skor tertinggi pada tes awal nilai tertinggi adalah 100, sedangkan pada tes akhir 98 hal tersebut terjadi karena kurang lengkapnya srtuktur teks ulasan pada tulisan sehingga mengurangi skor penilaian, tetapi pada kategori aspek penilaian lainnya sudah lebih berkembang.

Berdasarkan uji hipotesis nilai ratarata (mean) pada hasil pre-test kelas kontrol adalah 78,44, sedangkan rata-rata (mean) pada hasil post-test adalah 89,78. Jika dilihat hasil nilai rata-rata post-test kelas kontrol lebih tinggi dari pada mean pre-test hal itu karena pada post-test sudah diberikan materi pembelajaran mengenai teks resensi. Peningkatan yang terjadi antara nilai pre-test dan post-test adalah 11,34 poin.

Kelas eksperimen adalah kelas yang diterapkan penggunaan media audio visual dalam proses pembelajaran. Kelas eksperimen diberi perlakuan dengan menerangkan cara menulis teks resensi berdasarkan film yang telah ditentukan. Sama seperti pada kelas kontrol kelas eksperimen juga diberlakukan pre-test dan post-test. Proses pemberian

pre-test sama halnya dengan kelas kontrol dilakukan secara daring (dalam jaringan) melaui via WhatsApp dengan mengirimkan foto hasil keterampilan menulis teks resensi. Post-test yang dilakukan pada kelas eksperimen selain pemberian materi berupa video pembelajaran juga diberlakukan film yang telah ditentukan oleh peneliti.

Hasil pre-test berdasarkan hasil tulisan siswa terlihat masih sangat kurang. Terlihat siswa kurang dalam kreativitas dalam menulis, kelengkapan informasi dalam menulis teks resensi kurang lengkap bahkan ada yang tidak menuliskan identitas film sama sekali, 
struktur teks ulasan ditulis tidak secara runtut, pemilihan kata kurang tepat seperti kesalahan dalam penulisan ejaan. Jika dilihat antara pre-test kelas kontrol dan juga pre-test kelas eksperimen keduanya melakukan kesalahan yang sama. Kelas eksperimen melakukan kesalahan yang sama dengan kontrol begitu juga sebaliknya.

Hasil post-test dari penulisan siswa dalam menulis teks resensi kelas eksperimen berdasarkan beberapa hasil post-test siswa tersebut terlihat sudah mengalami peningkatan baik dari segi kreativitas dalam menulis, kelengkapan informasi sudah mulai jelas, dan beberapa penulisan ejaan sudah mulai baik. Siswa dapat menuliskan teks resensi sesuai dengan film yang ditonton, penggunaan media audio visual berupa video pembelajaran terkait materi teks resensi yang ditonton secara cermat dapat melatih siswa dalam menuliskan sebuah teks resensi sesuai dengan ketentuan dan juga dapat memberikan hasil yang lebih baik.

Berdasarkan uji hipotesis didapatkan nilai rata-rata (mean) pada hasil pre-test kelas eksperimen adalah 68,22 , sedangkan nilai rata-rata (mean) pada hasil post-test adalah 90,89. Hasil post-test siswa pada kelas eksperimen lebih tinggi dari pada hasil pre-test hal tersebut karena pada post-test sudah terlebih dahulu diberikan materi penggunaan media audio visual tentang teks resensi. Peningkatan yang terjadi antara nilai pre-test dan post-test pada kelas eksperimen adalah sebesar 22,67.

\section{PENUTUP}

Hasil penelitian memperlihatkan perbedaan nilai rata-rata pre-test dan posttest kelas eksperimen dan kontrol. Ratarata nilai pre-test kelas kontrol yaitu, 78,44 , sedangkan nilai pada hasil post-test adalah 89,78 . Nilai rata-rata (mean) pada hasil pre-test kelas eksperimen adalah 68,22 , sedangkan pada hasil post-test adalah 90,89. Hasil tersebut memperlihatkan terdapat pengaruh yang signifikan dari penggunaan media audio visual terhadap keterampilan menulis teks resensi dengan kata lain $\mathrm{H}_{\mathrm{a}}$ diterima dan $\mathrm{H}_{0}$ ditolak.

\section{DAFTAR PUSTAKA}

Afianti, Nur. 2014. "Pengaruh Penggunaan Media Audio Visual Terhadap Peningkatan Keterampilan Menulis Puisi Siswa Kelas IX MTS Jabal Nur Cipondoh Tangerang Tahun Pelajaran 2014/2015". Skripsi (internet), (http://repository.uinjkt.ac.id) diakses tanggal 11 Agustus 2020.

Agustin, Muliani. 2017. "Peningkatan Kemampuan Menulis Resensi Novel Menggunakan Stategi Pemodelan". Jurnal Diksatrasia, Volume 1, Nomor 2 Agustus 2017.

Dalman. 2014. Keterampilan Menulis. Jakarta: Raja Grafindo Persada.

Halifah, Nur. 2015. "Pengaruh Media Gambar pada Kemampuan Menulis Teks Prosedur Pembelajaran Bahasa Indonesia Siswa Kelas VIII SMP Negeri 9 Mataram Tahun 2015/2016". Skripsi (internet), (http://eprints.unram.ac.id). diakses tanggal 22 Februari 2020.

Hutabarat, Citra Ferawati. 2017. "Upaya Meningkatkan Kemampuan Menulis Siswa dengan Menggunakan Model Pembelajaran Kontekstual pada Mata Pelajaran Bahasa Indonesia Materi Menulis Laporan Pengamatan Kelas V di MIS Qoriah Fadhillah". Skripsi (internet),

(http://repository.uinsu.ac.id). di akses tanggal 17 Februari 2020.

$\begin{array}{rrr}\text { Kharisma, Nur } & \text { Ixanie. } & 2018 . \\ \text { "Pengembangan } & \text { Media } & \text { Audio } \\ \text { Visual } & \text { Untuk } & \text { Pembelajaran }\end{array}$ 
Menyimak Bahasa Prancis Kelas XI SMA/SMK”. Skripsi (internet), (http://eprints.uny.ac.id). diakses tanggal 11 Agustus 2020.

Khotimah, Husnul dan Kartika Chrysti Suryandari. 2016. "Analisis Kesulitan Menulis Karangan pada Siswa Kelas VI SDN 2 Panjer". Jurnal FKIP UNS.

Kurnia, Dadang, Jayadinata, Asep Kurnia, dan Ahmad Fujiyanto. 2016. "Penggunaan Audio Visual Untuk Meningkatkan Hasil Belajar Siswa pada Materi Hubungan Antarmakhluk Hidup". Jurnal Pena Ilmiah, Vol 1, No. 1: 842.

Mayaningrum, Astarina Siska. 2010. "Peningkatan Kemampuan Menulis Resensi Siswa Kelas XII IPA 1 SMA Negeri 3 Jombang dengan Menggunakan Metode CIRC". Karya Ilmiah.um.ac.id. diakses pada tanggal 01 Maret 2020.

Pohan, Eli Yulidar. 2014. "Pengaruh Model Pembelajaran Collabirative Learning Terhadap Kemampuan Menulis Cerpen oleh Siswa Kelas XI SMA Persiapan Stabat Tahun Pelajaran 2013/2014”. Jurnal Online. diakses pada tanggal 06 Maret 2020.

Rakhman, Maman, Hasan, Syamsuri, dan Andriana Johari. 2014. "Penerapan Media Video dan Animasi pada Materi Memvakum dan Mengisi Refrigeran Terhadap Hasil Belajar Siswa". Jurnal of Mechanical Engineering Education. Volume 1, No. 1 Juni 2014: 9-10.

Rahmawati, Eriah. 2011. "Peningkatan Keterampilan Menulis Resensi
Buku Melalui Metode Pembelajaran Berdasarkan Masalah Menggunakan Teknik Membandingkan pada Siswa Kelas XI IPA 1 SMA Negeri Bawang Kabupaten Banjarnegara”. Skripsi (internet), (https://lib.unnes.ac.id). diakses tanggal 22 Februari 2020.

Septiaji, Aji. 2015. "Membangun Keterampilan Menulis". Dalam Kompasiana. Edisi Selasa, 26 Februari 2013. Jakarta.

Windari. 2016. "Pengaruh Penggunaan Media Film Terhadap Keterampilan Menulis Cerpen Siswa Kelas XII SMA Negeri 1 Lengayang Kabupaten Pesisir Selatan". Skripsi (internet),(http://repo.stkip-pgrisumbar.ac.id). diakses tanggal 17 Februari 2020.

Yuliapitri, Idriani. 2016. "Hubungan Kemampuan Memahami Resensi dengan Kemampuan Menulis Resensi Siswa Kelas XI IPA SMA Negeri 2 Tilatang Kamang Kabupaten Agam". Skripsi (internet), (https://repo.stkip-pgrisumbar.ac.id). diakses pada tanggal 5 Maret 2020). 